\title{
Social Cultural Stressors in Dominican Republic HIV/AIDS Prevention and Treatment
}

\section{Pilar Horner ${ }^{1 *}$ and Reza Nassiri²}

${ }^{1}$ School of Social Work and the Julian Samora Research Institute, Michigan State University, USA

${ }^{2}$ Institute of International Health, Michigan State University, USA

\begin{abstract}
Despite the wide access to anti-retroviral medications to combat HIVIAIDS, the Dominican Republic (DR) has the second highest numbers in HIV prevalence in the Caribbean and Latin American region. Knowledge gained from previous research still struggles to explain how socio-cultural factors effect prevention and treatment. Few studies rigorously examine the manner in which Dominicans face unique social and cultural challenges with diagnosis. Syndemic theory frames this paper in order to capture the importance of socio-cultural interconnections within the HIVIAIDS population in the DR. Particularly, this paper focusses on the social and behavioral difficulties of HIVIAIDS prevention and treatment. This study took place in Boca Chica, Dominican Republic, at a small HIVIAIDS clinic near the tourist quarter. Qualitative methodologies are employed with in-depth interviews, memos, and participant observation of group charlas (educative talk sessions), and visits the community medical center and patients' neighborhoods. A syndemic was confirmed of neighborhood effects, malnutrition, and HIVIAIDS diagnosis. Particular attention was paid to disparities of gender, economic class, and employment.
\end{abstract}

Keywords: Dominican Republic; Social/Behavioral health; Qualitative methodology; HIV/AIDS; Syndemic theory

\section{Introduction}

Yo pienso que ustedes deben visitar a los pacientes que están en el hospital, caso por caso y ver las condiciones que vive cada uno y ver con sus propios ojos. (Guillermo, 36)

I think you should visit all the patients that are in the hospital, case by case, and see the conditions that they live in, with your own eyes. (Guillermo, 36, diagnosed with HIV)

A fundamental challenge of HIV/AIDS prevention and treatment work in resource-limited countries lies with enhancing knowledge of how cultural, social, and economic conditions impact biological disease progression to improve health and decrease debilitating outcomes. Thus, barriers to care and prevention emerge despite best efforts to control and manage the effects of disease progression. This can be seen clearly in the case of the Dominican Republic (DR). Despite the wide access to anti-retroviral medications to combat HIV/AIDS, the DR has the second highest numbers in HIV prevalence in the Caribbean and Latin American region [1]. In 2009, over 57,000 Dominicans were living with HIV/AIDS (WHO). Reports show that unprotected sex, sex with multiple partners, sex workers and their clients and partners, men who have sex with men (MSM), drug users in particular, injection drug users (IDUs) and/or members of mobile subpopulations that engage in risky sexual behaviors drives the DR's HIV/AIDS epidemic. According to USAID [2], HIV/AIDS passes along mostly through heterosexual sex, among women with four or fewer years of formal education and who live in highly segregated and poor areas such as sugar cane plantations. Other factors that put the Dominican Republic population at risk of HIV/AIDS include early age of sexual debut and the Dominican Republic's popularity as a tourist destination coupled with increasing levels of sex tourism. These and other factors suggest the need to target interventions to young adults, provinces with high rates of tourism, women with low education levels, men who have sex with men, IDUs, and bateyes ${ }^{1}$ [2].

Despite the knowledge gained from previous research, little

1 Bateyes are residential areas in plantations usually marked by high poverty. is known about how socio-cultural factors effect prevention and treatment. For example, scholars identify machismo as a common cultural indicator for men in Spanish-speaking countries. Though machismo certainly manifests in the Dominican Republic scholars do not completely understand how these realities impact individual decision making within the community. Few studies rigorously examine the manner in which Dominicans face unique social and cultural challenges with diagnosis. To capture the importance of socio-cultural interconnections within the HIV/AIDS population in the DR, syndemic theory frames this study. Syndemic theory posits that a syndemic is a "concentration and deleterious interaction of two or more diseases or other health conditions in a population, especially as a consequence of social inequity and the unjust exercise of power" [3]. This study uses the syndemic framework to examine how multiple diseases impact an individual and their ability to engage prevention and treatment care within the particular population of poor and unemployed Dominicans. Particularly, this paper focusses on the social and behavioral difficulties of HIV/AIDS prevention and treatment. Using syndemic theory offers a mechanism to address why interventions of diseases fail to fully address the multiplicative externalities of various effects. These multiple diseases affect individuals and communities in compounding and stressful ways, causing limited successful impact (even when medical care is available and effectual).

The Caribbean offers a significant and important site for research on effective HIV/AIDS prevention and treatment. Extremely high prevalence rates occur in this geographic area, exceeding most countries except sub-Saharan Africa [4]. Even with significant PEPFAR

${ }^{*}$ Corresponding author: Pilar Horner, Michigan State University, USA, E-mail: phorner@msu.edu

Received July 29, 2013; Accepted August 28, 2013; Published September 06 2013

Citation: Horner P, Nassiri R (2013) Social Cultural Stressors in Dominican Republic HIVIAIDS Prevention and Treatment. J AIDS Clin Res 4: 242. doi: 10.4172/2155 6113.1000242

Copyright: (C) 2013 Horner $P$, et al. This is an open-access article distributed unde the terms of the Creative Commons Attribution License, which permits unrestricted use, distribution, and reproduction in any medium, provided the original author and source are credited. 
(U.S. President's Emergency Plan for AIDS Relief) interventions and access to ARV Therapy, HIV/AIDS incidence rates fail to dramatically lessen. This study closely examines how individuals understand and make sense of their choices regarding HIV/AIDS prevention and treatment, and how high-risk demographic indicators contribute to their decision making capabilities. The study aims to consider how multiple disease impact the burden of disease and the potential outcomes to improve health by looking at how living with HIV/AIDS, malnutrition, environmental violence within the context of social and health disparities affects outcomes for Dominicans. The orientation focuses on synergistic effects rather than discrete moments, and takes into account the holistic picture of disease in order to better treat and prevent illness.

\section{Methods}

This study draws on a pilot research project. Prior to data collection, the Institutional Review Board approved all study aspects and all participants signed informed consent forms. An ethnographic qualitative study guided the research study, using interviews and participant observation. Eleven one-on-one individual in-depth interviews occurred, and two observations of group counseling sessions (charlas) for patients at-risk of HIV. Of the eleven interviews nine were female and two were male. Ages ranged from 18 to 56. Open-ended questions were loosely drawn from existing literature that examine socio-cultural issues related to disease treatment and prevention including questions regarding access to care, economic issues, cultural issues (food, religion, and so on). In addition, prompts were used to further propel respondents' answers. Finally, at the end of the interview, participants were encouraged to contribute other questions or issues they had about their care, the community, and issues in general as related to HIV/AIDS prevention and treatment.

\section{Study site: The Boca Chica Clinic}

The Hospital General Boca Chica in Andres Boca Chica houses the HIV/AIDS clinic. Patients come from the surrounding areas, which are all located on the southern side of the DR approximately one hour from the capital of Santo Domingo. The clinic provides HIV care for the resource limited community. The HIV/AIDS section of the clinic is open daily from $8 \mathrm{am}$ until noon, and treats over 300 patients who have been diagnosed with HIV/AIDS. Though most patients are adults, health care providers treat approximately ten to twenty children. During clinic hours, two main activities take place. First, community charlas or talks are conducted in a small $12 \times 12$ cement room. A central table allows for individuals to sit around in conversation style, and overflow participants sit along the walls or stand near the hallway. The charlas aim discussion at understanding common misunderstandings of HIV, and how to utilize the clinic and treatment options. The discussions are open, and at times men and women freely ask questions and discuss community issues. The charlas last approximately thirty minutes after which individual patient visits commence. Patients meet privately with the physician and nurse for ten to thirty minutes.

The clinic maintains one waiting room, a smaller room for stored medical records, one exam room/office space for the physician and nurse, a closet for storage of medicines, and a modest bathroom. The building contains no central air, which contributes to the one morning visiting hours as the heat intensifies as the afternoon progresses.

The medical director in charge of the clinic trained and worked as a nurse, then as a doctor at the Universidad Central in Santo Domingo and worked as a generalist in the Boca Chica Hospital for 12 years. She trained as a specialist in HIV care and continues to attend workshops and trainings. At this time, her HIV practice includes approximately 125 active patients on medications and over 200 that have been tested and are in regular contact for evaluation but are not on ARV. In addition, some 200 are either missing, not complying with their care, or have dropped out of sight.

In the afternoon, the staff social worker does unpaid home visits throughout the outlying neighborhoods to ensure that individuals come to the clinic and receive care. He travels mostly by small motorcycle, but once in the community he walks for hours to try to contact patients. The neighborhoods vary in terms of economic and social supports and resources, but range from working class/poor to destitute. Patients, families, and community members all know the social worker by sight. He elicits trust from the community and his reputation indicates his importance and credibility.

All interviews were conducted in Spanish with no translators. All data was recorded digitally and uploaded to a secure website for transcription. Once transcribed from original Spanish, the data was uploaded to MAXqda, a qualitative software program. All analysis was conducted in the original Spanish and translated for purposes of reporting only. Data was analyzed for patterns and reoccurring themes $[5,6]$. Ethnographic content analysis enabled the ability "to document and understand the communication of meaning, as well as to verify theoretical relationships" [7]. Inductive analysis techniques enabled the creation of codes, and then categories and larger themes emerged to further explicate the syndemic.

\section{Results and Discussion}

A prominent syndemic emerged impacting HIV/AIDS prevention and treatment services for Dominicans in Boca Chica. Access to appropriate medication was not the major concern or issue affecting this impoverished community, rather a combination of socio-cultural stressors within a dynamic of economic disparities emerged as the major issues to address with this population. The data showed that a syndemic emerged of HIV/AIDS, malnutrition, and neighborhood effects most affected this population.

As seen in Figure 1, the interaction of the three health concerns occur within the context of extreme social and health inequalities. When a patient is at the nexus of the intersecting circles, then a multiplicative effect occurs as theorized by the syndemic framework. The following data illustrates first how individuals understand the individual health issues, and secondly how they make meaning of those understandings within the context of disparities (or how they the

Underlying Social Inequalities and Health Disparities

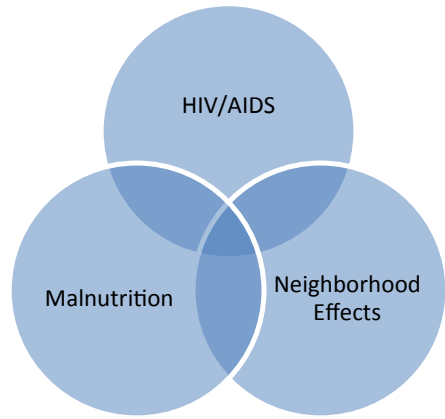

Figure 1: Syndemic of HIVIAIDS, Malnutrition, and Neighborhood Effects. 
patients conceptualize what we call social and health inequalities). The obstructions to treatment and prevention strategies signify the presence of a complex syndemic.

\section{Malnutrition}

Malnutrition emerged as a major issue. In order to avoid serious complications from ARV treatment, an adequate diet is necessary. Factors that contribute to malnutrition for infected patients may include loss of appetite, poor ability to absorb nutrients, and forgetting to eat due to AIDS related dementia [8]. In addition to these issues, individuals from disadvantaged environments risk higher levels of malnutrition in part due to limited access to proper nutritional sources [9]. Interviews with patients at the Boca Chica clinic demonstrated important structural and cultural realities which patients must navigate.

\section{Accessing food possible through family networks}

Accessing, purchasing, and preparing foods revealed cultural patterns that complicated patient care. One example of this is when a patient described the mode in which they accessed food.

No, la hermana mía que cobra y tengo hermano que me ayudan. Misher manosme quieren mucho. Porque antes de esto, yo era bueno. Yo le estaba haciendo la casa a mi mamá cuando trabajaba y la he dejado y no está terminaba porque no tengo trabajo. No puedo seguir trabajando. En el trabajo no me aceptan. (Alberto, 41).

No, my sister pays for my food, and I have siblings who help me. My siblings love me a lot. Before this [HIV diagnosis] I was fine. I was helping out at home when my mom worked, and now I don't because I don't have a job. I can't continue to work. At my workplace, they don't accept me (Alberto, 41).

This quote shows that Alberto contributed to the home with his paycheck but after being fired due to his diagnosis he longer works. Still, his needs are met by his sisters and brothers who care for him. It is the family context here in which Alberto receives support for his nutritional needs. It was often the case that men and younger women who were interviewed relied on others in their lives to help maintain their nutritional needs, while the older women in the study discussed the strain of having to provide for themselves and their families. In the following quote, a young woman notes this reliance on family:

Bueno, yo sé que mi alimentación debería ser bien alta, pero la situación a veces no me lo permite. Por el dinero, por la situación económica. Hay cosas que you debería comer que sé que me alimentan. Como ensaladas, broccoli, coliflor, como el hígado de res, de la vaca y cosas así como los jugos. Porque el virus es fuerte, entonces hay que proteger la pared del estómago. Duele mucho el estómago. Si se toma con agua, duele mucho. Pero a veces si no hay con que tomárselo, hay que tomarlo con agua porque no se puede pasar de la hora. Entonces yo cumplo con eso, con el horario. Bueno, en la mañana a veces pan que no es lo correcto, que ellos me lo han dicho, a veces plátano... No, café no. Si puedo leche o té, el arroz, al mediodía el arroz, las habichuelas, siempre la harina de maíz que alimenta mucho y me favorece a mí porque me ayuda mucho, la avena... Yo le digo a mi padre y él va y me compra un poco de todo, algunas cositas... Hay supermercados que no son muy caros. En el supermercado que queda cerca no venden fruta fresca. No son supermercados de mantener fruta fesca, ni víveres frescos, nada de eso, sólo cosas de latas....Es difícil porque me queda lejos, la distancia. Por suerte tengo a mi padre que él va dondequíera. Mi familia me apoya mucho. Él va a pie. Va caminando. Cuesta mucho, es difícil, muy difícil. (Catalina, 25).
Well, I know that my diet should be substantial, but sometimes my situation does not allow me. Due to money, due to my economic situation. There are things I know I should eat to keep up my diet. Such as salads, broccoli, cauliflower, and beef liver, cow and stuff like juice. The virus is strong, so one must protect the stomach wall. The stomach can hurt a lot. If [the anti-retroviral drugs are] taken with water, it hurts. But sometimes if there is nothing else, [the drugs] must be taken with water because you can't miss your dosage. Then comply with that, I comply with the schedule [for taking medications]. Well, in the morning sometimes [I eat] bread that is not the right kind, they have told me, sometimes a banana ... No, coffee, no. If I can have milk or tea, rice, for lunchtime rice, beans, cornmeal. I prefer cornmeal because it fills me up, and helps me a lot. Oats too... I tell my father and he goes and buys me a little of everything, some little things. Supermarkets ... are not very expensive. In the supermarket close to me, they don't sell fresh fruit. The supermarkets don't sell fresh fruit or fresh food, none of that, only canned stuff ... It's hard because I live so far away. Luckily I have my father who can go wherever he wants to. My family supports me a lot. My father will walk. It takes a lot out of him, it's difficult, very difficult (Catalina, 25).

In the above quote, Catalina clearly understands the necessary diet her body needs to combat the effects of her diagnosis. However, the reality of her poverty and the inaccessibility to affordable fresh food impacts her treatment; this partly explains why she relies on the inexpensive and available cornmeal. Without the help of her elderly father however, who cannot walk very far, she would be unable to eat as she does. Catalina at age 25 depends on her family network in order to survive. Still, the emotional pain of seeing her father having to physical exert himself in the time of life when the child should be helping to support the parent weighs on Catalina. She repeats "it's difficult" twice to add emphasis on her own weariness of having her father care for her in his old age.

Gender also plays an important role in how HIV patients understand their treatment and life with the disease. In the following quote, Demaris, a mother, describes her difficulties in keeping food on the table for her family:

Muy, muy difícil. Porque como no estoy trabajando, entonces, no puedo, hay veces que como me levanto, me acuesto. A veces es muy difícil.... no es que sea muy caro, es que si uno no tiene dinero es muy difícil. A veces por tener muchos niños a veces no tengo para cocinar. Yo debo comer cuando hay (laughter) que a veces no hay. A veces lloro porque no tengo al esposo. A veces lloro porque... ya los grandes aguantan, como por ejemplo si tengo hambre quedarme callada, pero cuando los más chicos me dicen que no aguantan porque tienen hambre, ahí me dan cosas y me pongo triste porque no tengo las facilidades de darle la comida. A veces si pasa alguien yo le digo que me den cien o cincuenta pesos o caulquier cosa (Demaris, 42).

[Getting food is] very, very difficult. Because as I'm not working, then I cannot [eat], there are times that [I think] "how will I get up", and I lie back down. Sometimes it is very difficult....not that it [food] is very expensive, it's that if one has no money is very difficult. Sometimes because I have so many children sometimes I don't have enough to cook with. I must eat when there is [food] (laughter) but sometimes there is not. Sometimes I cry because I have no husband. Sometimes I cry because ... the older children endure, for example [they may think] if I am hungry I have to stay quiet, but when the smaller children tell me they cannot stand it because they are hungry, then I get sad because I don't have the ability to give them food. Sometimes if someone passes by, I tell them to give me a hundred or fifty pesos or anything (Demaris, 42). 
Demaris demonstrates several key moments in understanding how families operate in the Dominican Republic. In comparison to Alberto and Catalina, Demaris' case shows no family networks that she can rely on for help with food, and subsequently she and her children go hungry. In addition, as a mother her children rely on her to provide them with the necessary diets, but due to her condition (and her inability to be employed as a result of her diagnosis) she cannot provide for them. In this way, without a husband or family to help her, Demaris' chances of successfully fighting her HIV diagnosis is significantly compromised. Her sadness over not being able to provide for her children or attend to basic caregiving tasks weigh heavily on Demaris. This added stress and emotional strain diminish her stamina and strength.

\section{Neighborhood effects/violence (transportation, safety)}

According to scholars, neighborhood effects impact outcomes for individuals in four significant ways: social ties/interaction, norms and collective efficacy, institutional resources, routine activities [10]. Various interviewees highlighted how neighborhood effects impacted their overall health and their access to resources. One factor that has shown independent validity has to do with neighborhood organizations, access, and membership. The following quote demonstrates how participants understood the resources available in where they lived:

No, no hay organizaciones, sino que los muchachos del barrio son muy unidos y si vienen otros de otro barrio a buscar problemas, ellos les dan problemas, pero yo no comparto eso con ellos porque a mí los problemas no me gustan. Si yo me meto y no quiero verlos pelear los puedo desapartar y les digo no más pelea, entonces no pelean, pero no me meto porque no esbueno. Porque los problemas te vienen.... Y es posible que vayas a la cárcel, entonces el otro es muerto y usted es preso. (Alberto, 41).

No, there are no [neighborhood] organizations, but the neighborhood boys are very united and if others come from another neighborhood looking for trouble, they take care of it, but I don't get involved with them because I don't like problems. If I do get involved and I do not want to see them fight I can intervene and tell them to stop fighting, but I don't get involved because it's not good. Because problems will come... and you may go to jail, or the other guy end updead and you are imprisoned (Alberto, 41).

For Alberto, his social ties clearly link with groups of young men that patrol and police their neighborhood. Alberto makes some troubling comments about his tenuousness in being involved with vigilante groups, and trying to avoid problems. However, as he puts it "problems will come" and it is clear from his statement above that just by living in his neighborhood he is at higher risk of encountering outside negative influences.Such living conditions are highly provoking, especially for Alberto who manages his diagnosis along with environmental violence.

Another startling aspect of neighborhood effects can be seen in the following quote from Beatriz:

Nunca he tenido molestias ahí, gracias a Dios.

\section{I: ¿Y habla con sus vecinos?}

¡Hmmm! Yo no soy mjuy compartidora, pero (laughter) me llevo bieno con todo el mundo. Bueno, hay la junta de vecinos. Ayudan si no hay agua en el sitio, lo que sea cualquier cosa; ellos ayudan mucho. Hace como dos años mataron a un muchacho ahí (frente de mi casa). Un delincuente que venía de otro sitio, no era de ahí. Porque era ladrón. La policía lo mató. La policía vino y lo mató. He tenia veintidós años. Sí, aquí hay mucho problema, de drogas y de todo. Yo no me explico por qué ha surgido. Donde yo vivía antes tuve que salir por eso. Había mucha droga, mucha cosa, y mis hijos grandes, grandes ya (Beatriz, 53).

Hmmm! I'm not very neighborly but (laughter) I get along with everyone. Well, there's the neighborhood committee. They help if there is no water, with whatever thing, they help a lot. About two years ago they [delinquents] killed a boy there (in front of my house). Someone came from another neighborhood, he was not from here. Because he was a thief, the police killed him. The police came and killed him. He was twenty-two. Yes, there's a lot of problems, drugs and everything. I cannot understand why it has emerged. Where I lived before I had to move because of the same thing. There were a lot of drugs, a lot of things, and now my kids are grown, grown already (Beatrice, 53)

Beatrice perfectly illustrates the intense violence that she lives with daily, not only does she have to manage lack of resources such as running water, but in addition she witnessed a murder right in front of her own home. What is most interesting is that Beatrice clearly understands the negativity of living in a neighborhood with drugs and violence and has tried to move once before. However, she is unable to escape the violence and she is somewhat confused as to why the danger has emerged in her neighborhood. Her inability to connect her poverty with the emergence of drugs and violence in her neighborhood demonstrate that Beatrice's is deeply embedded in her social framework. For Beatriz, her neighbors know her but there does not exist a strong community of looking out for one another, also the daily assault of violence impacts Beatriz's mental and emotional well-being.

The violence continues for other participants as well, and the concern for children (grown or not) continues to drive parental stress, as seen in the following quote:

[Hay] mucha delincuencia. Los maestros están trabajando con eso, porque están viendo a los niños que están copiando mucha violencia de otros lados que ellos ven. (Catalina, 25).

[There is] a lot of crime. Teachers [in the schools] are working with that, because they are seeing children copy the violence they see from other places (Catalina, 25)

In all of the above quotes, the violence is perceived to come from somewhere else, an outside predatory threat. And this perception of neighborhood violence has been shown to be deleterious to individuals' well-being and sense of agency [11]. In other words, the externalization of threat or harm negatively impacts an individual and community's efficacy and their ability to impact the health of their lives. This learned hopelessness [11], dramatically weakens well-being.

Another form of stress that impacts these participants is the lack of neighborhood resources available in their own homes. Demaris (42) describes the difficulties of managing her home with only limited access to electricity:

No, la luz se va a las 5 de la mañana y vuelve casi a las 11 de la mañana. Se va a la una de la tarde y viene a las 6 de la noche. Todos los días, aquí, varios sitios son así. En Boca Chica no se va la luz. Y es porque es vía de turistas y no se va la luz en Boca Chica, pero aquí se va mucho la luz y como van a la escuela, por la mañana están en la escuela no están pendientes si hay luz o no hay luz.

I: Eso es difícil cuando tienes un refrigerador, ¿no es cierto? ¿qué pasa con la comida?

D: Para los que lo tienen, es muy difícil. Yo no tengo. (Demaris, 42)

No, the lights go out at five in the morning and come back at $11 \mathrm{am}$. 
It goes at one in the afternoon and comes at six at night. Every day, here, various homes are like this. In Boca Chica [main city] the lights don't go out. This is because it's the tourist area and the power does not go out Boca Chica, but here it the electricity goes out a lot, and for those that go to school, in the morning when they are at school they never know if they will have electricity or not.

I: That's difficult when you have a refrigerator, is not it? What about the food?

D: For those who have a refrigerator, it is very difficult. I don't have one (Demaris, 42)

Demaris statements about the uncertainty of electricity and her own lack of resources for food maintenance contribute greatly to her stress in terms of watching her disease progression. Her living conditions are highly stressful with intermittent electricity. She is also very aware that there is electricity to be had (in the tourist area of Boca Chica) but her quotes illustrates that she believes her life is not viewed as important as the tourists. She must go without. In addition, if she could access fresh foods, she would have no way to keep them from rotting, as she lacks even a small refrigerator for her and her family's needs.

In many ways, the neighborhood issues that impact the health conditions of these patients can be summed up by Flor, a thirty five year old mother, who stated that "No hay problema. Si hay dinero, no hay problemas (laughter)." "There are no problems, if you have money, there are no problems (laughter)" (Flor, 35). The poverty and neighborhood violence, drugs, lack of resources all contribute to the high stress of these participants and negatively impact their ability to manage their health. However it is not just not having resources that impacts these patients, it is the acute awareness that supports exist but that these individuals cannot access them.

\section{HIV/AIDS}

Various issues emerged for patients infected with HIV/AIDS at the Boca Chica clinic. This section in particular looks at their care and understanding of their diagnosis and the disease itself. Access to care continued to emerge as a prominent theme for individuals. Although the clinic itself was able to manage their health, for blood work, and more complex testing, patients had to make a long trip (and expensive for many) to the capital in order to visit the main hospital. Alberto, below comments on the difficulties of this:

Muy bien, pero....hacen falta unos cuantos recursos para uno. Pues si uno consigue 500 pesos para comérselos, tiene que gastarlos cuando ya decide que tiene que hacerse análisis en la capital para ver como uno sigue, para ver como uno está y que si eso está aquí sería mejor. Porque hay que ir para allá, a la capital. (Alberto, 41).

Very good, but ....one lacks certain resources. For example, if one gets 500 pesos for food, you can only spend them when you have to have blood work done in the capital, to see how one gets along, to see how you are, and if it would be better to stay here. Because you have to go there, to the capital [for those tests] (Alberto, 41).

Alberto is attempting to communicate that with his limited resources, a patient must always be making decisions between being able to eat, or meet some small basic needs, versus using the few resources one has to go to the capital to have tests done. Many patients echoed Alberto's concerns, and noted that not only did they have to take the tests, but the costs included transportation, eating along the way, waiting for long hours in the hospital, and have to return late in the day to their homes (sometimes during unsafe hours). In addition, many patients felt humiliated by the treatment they received in the capital, in comparison to the care they felt they received at the Boca Chica clinic. These experiences further solidified for the patients that their lives mattered little.

Another issue that arose described clear gender inequalities especially in terms of infection risk:

I: Yo estabaescuchando en la charlacuando las mujeresestabanhablando que sus esposos las contagiaron. ¿Cómo se puedeprevenireso?

R: Yo no sé, porqueyo no sécomosucedióeso lo mío y lo de él. Porqueyonuncapenséeso. Pero las cosassuceden. Escosa de la vida. Bueno, mire éseesunproblema que no se puedeevitar, porque el hombre esmachistasiempre. Sale a la calle y nosotras las mujeresdelhogar no noscuidamos con las parejas, ahíesdondeestá el problema. Es que no noscuidamos, así de fácil. No nosponemospreservativos o algo. Siempre uno tieneconfianza en sumarido.Ahíesdondeestá el problema, porqueyo soy hasta evángelica. Esees el problema, pero Dios sabe lo que hace. (Beatriz, 53)

I: Yo estaba escuchando en la charla cuando las mujeres estaban hablando que sus esposos las contagiaron. ¿Cómo se Puede prevenir eso?

R: Yo no sé, porque yo no sé como sucedió eso lo mío y lo de él. Porque yo nunca pensé eso. Pero las cosas suceden. Es cosa de la vida. Bueno, mire ése es un problema que no se puede evitar, porque el hombre es machista siempre. Sale a la calle y nosotras las ujeres del hogar no nos cuidamos con las parejas, ahí es donde está el problema. Es que no nos cuidamos, así de fácil. No nos ponemos preservativos o algo. Siempre uno tiene confianza en su marido. Ahí es donde está el problema, porque yo soy hasta evángelica. Ese es el problema, pero Dios sabe lo que hace. (Beatriz, 53).

Beatrice here echoes the sentiments of many women in the study who felt their infection was a passive action on their part. Their husbands infected them during unprotected marital sex, and they were shocked to discover that they had been infected. This pointed to a much larger issue of gender disparities and cultural acceptance, where many husbands were excused or even expected to go out and have extra marital affairs, and women paid the cost because as Beatrice points out "That's life." This blatant resignation also echoes in her invoking the phrase "God knows what he is doing" which ultimately excuses both her husband's behavior and her lack of agency to prevent her own infection.

This type of resignation and acceptance of male machismo behavior paired with religion consistently appeared, as seen in the quote below:

Lo que sucede que hay muchas religiones que son muy ignorantes $y$ fracasan al decirle a una persona enferma..., vamos a ponerle un ejemplo, yo con VIH voy a una iglesia cristiana, porque mayormente son los cristianos, y ellos saben que tengo el virus de VIH; ellos me dicen Dios te ha sanado. Entonces hacen que yo abandone mi medicamento, abandone mi terapia, por eso hay muchas personas que se han muerto. (Catalina, 25).

What happens is, is that there are many religions that are very ignorant and fail to tell a sick person ... we will give you an example, I'm HIV positive and I go to a Christian church, because they are mostly Christians there, and they know that I have the virus, and they tell me God has healed me. So do I leave my medication, quit my therapy?This is why there are many people who have died (Catalina 25). 
Catalina's shocking quote illustrated that religion and folklore still play a prominent role in the culture. The consequences of these beliefs led to the deaths of many AIDS patients who forgo treatment and place their care in their religion. These issues were also openly addressed during the charlas and many people recognized how folklore and religion did impede treatment and care for patients.

These three health conditions malnutrition, neighborhood effects, and HIV/AIDS infection were perceived by the respondents as being interconnected and having multiplicative effects on their well-being. In addition, in order to meet the definition of a syndemic these aspects occur within a context of severe health disparities. The above data indicates that most patients live in various levels of poverty, lack ability to attain employment due to their diagnosis, and rely on family members for most of their care. For women especially, particular stress and anxiety appeared when issues of caring for children, trying to get food, and managing the reality of their diagnosis.

\section{Conclusion}

Despite the knowledge gained from previous research, little is known about how the socio-cultural factors effect prevention and treatment. A concentration of multiple health conditions and social inequity verified a syndemic of HIV/AIDS, malnutrition, and neighborhood effects within social inequities. However, significant gender disparities exacerbated by cultural and economic divides disproportionately impacted women. Gender differences included partner infidelity, machismo, poverty, malnutrition, unsanitary and violent living conditions. This is a unique study in that it uses Syndemic Theory to the cumulative effects within environmental and social violence.

Multiple health conditions exacerbated by social and economic power inequalities lead to non-integrated approaches to care. Although marginalized health inequalities impacted women, participants rarely recognized the extent to which culture, poverty, and social forces impacted their treatment. Culturally competent prevention and treatment of HIV/AIDS in resource limited countries should consider targeted health care to address gender disparities.

Limitations of this study include a limited sample size, and also, lack of male representation. However, despite these limitations, this preliminary data does show that individuals living in severely resource limited environments, and who are diagnosed with HIV/AIDS face many stresses and anxieties that impact their overall health. Lack of access to (either through transportation or cost) sufficient diets impact nutritional necessities for patients. These individuals are prone to wasting syndrome and also face many difficulties with maintaining their health. Also, the violent and resource depleted homes do not provide enough stability for patients to recover and deal with their illness. Finally, the myths, gender discriminatory cultural myths and prevailing stigmas negatively impact individuals and their families and communities.

In order to improve outcomes for these communities, and following the framework of Syndemic Theory, a holistic approach to care that accounts for nutrition, living conditions, and HIV/AIDS treatment and care are needed to vastly improve outcomes for communities living in marginalized social spaces.

\section{Acknowledgement}

The authors would like to acknowledge their appreciation to the men and women of Boca Chica who openly and willingly contributed to this research project. In addition, we would like to acknowledge the following people for their time and efforts in this research project: Linda Williams, RN, Adonis Polanco, Dr. Altagracia

\section{References}

1. Arregui M (2007) Living with HIV in the Dominican Republic. Interamerican Journal of Psychology 41: 31-40

2. USAID (2010) USAID HIVIAIDS Health Profile for Dominican Republic.

3. Singer $M(2009)$ Introduction to syndemics: a critical systems approach to public and community health. Jossey-Bass Inc Pub.

4. Padilla MB, Guilamo-Ramos V, Bouris A, Reyes AM (2010) HIV/AIDS and tourism in the Caribbean: an ecological systems perspective. Am J Public Health 100: 70-77.

5. Patton MQ (2002) Qualitative research and evaluation methods ( $3^{\text {rd }}$ Edn.), Thousand Oaks, Califonia, Sage Publications.

6. Bryman A (2006) Integrating quantitative and qualitative research: how is it done? Qualitative Research 6: 97-113.

7. Altheide DL (1987) Ethnographic Content Analysis. Qualitative Sociology 10: 65-77.

8. Duggal S, Chugh TD, Duggal AK (2012) HIV and malnutrition: effects on immune system. Clin Dev Immunol 2012: 784740.

9. Mahlungulu S, Grobler LA, Visser ME, Volmink J (2007) Nutritional interventions for reducing morbidity and mortality in people with HIV. Cochrane Database Syst Rev 2: CD004536.

10. Sampson RJ, Morenoff JD, Gannon-Rowley T (2002) Assessing "Neighborhood Effects": Social Processes and New Directions in Research. Annual Review of Sociology 28: 443-478.

11. Horner P, Sanchez N, Castillo M, Delva J (2012) Parental perceptions of neighborhood effects in Latino Comunas: the script of "the Delinquent" in understanding drug use, violence, and social disorganization. Subst Use Misuse 47: 809-820. 